\title{
3 - Equívocos nas respostas à desindustrialização brasileira
}

\author{
Marcio Pochmann
}

SciELO Books / SciELO Livros / SciELO Libros

POCHMANN, M. Equívocos nas respostas à desindustrialização brasileira. In: Brasil sem industrialização: a herança renunciada [online]. Ponta Grossa: Editora UEPG, 2016, pp. 106-146. ISBN 978-85-7798-216-5. Available from SciELO Books $<$ http://books.scielo.org $>$.

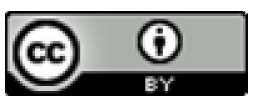

All the contents of this work, except where otherwise noted, is licensed under a Creative Commons Attribution 4.0 International license.

Todo o conteúdo deste trabalho, exceto quando houver ressalva, é publicado sob a licença Creative Commons Atribição 4.0.

Todo el contenido de esta obra, excepto donde se indique lo contrario, está bajo licencia de la licencia $\underline{\text { Creative }}$ Commons Reconocimento 4.0. 


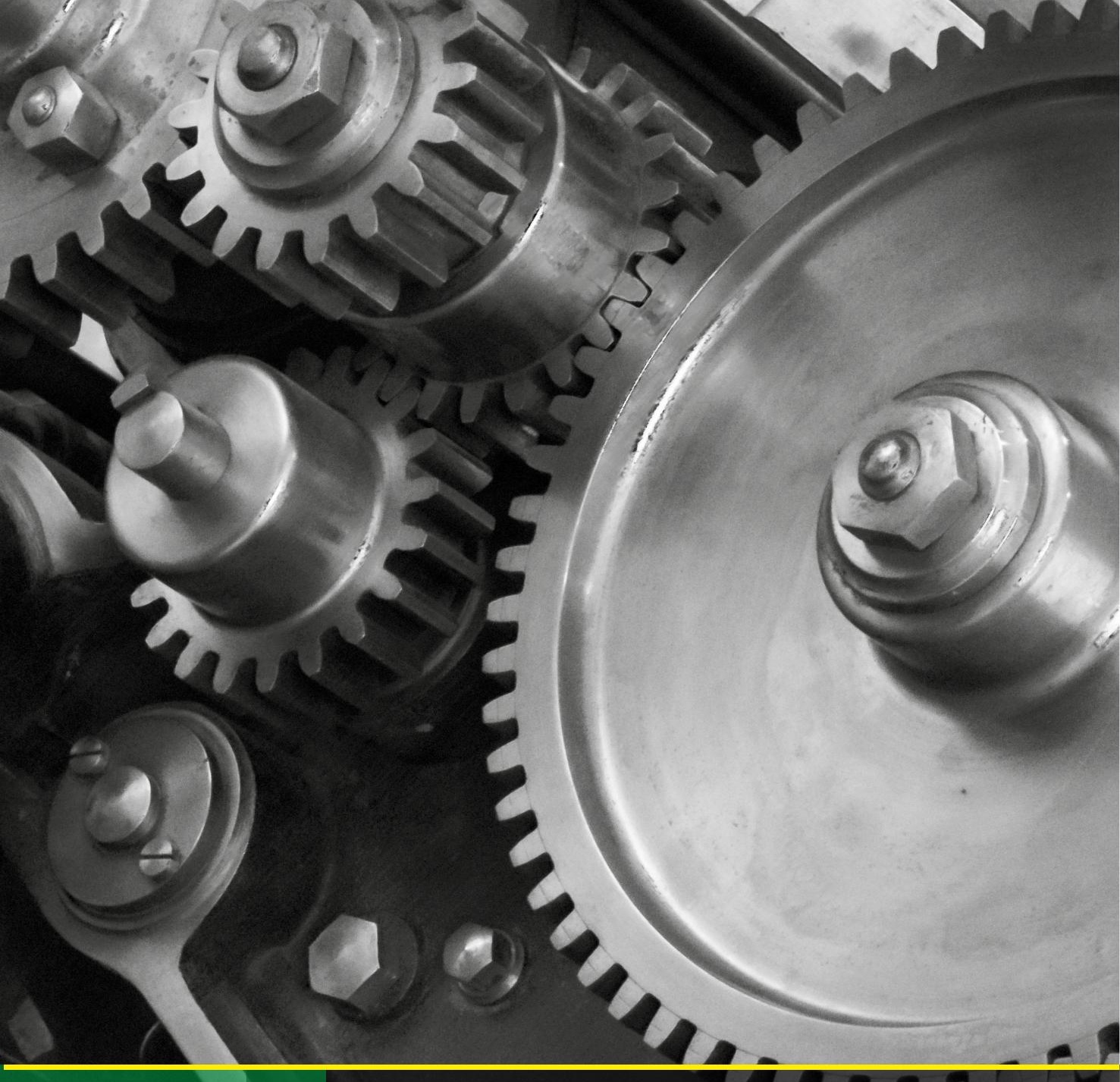


Ao final dos anos 1970, o Brasil situava-se entre as oito principais economias industrializadas do mundo. O incrível salto na constituição e difusão material das forças capitalistas numa economia periférica ao centro desenvolvido foi acompanhado por duas características especiais que se distinguiram das demais experiências de industrialização até então existentes.

A primeira característica associada ao processo de industrialização tardia no Brasil era a natureza produtiva internacionalizada e social extremamente excludente, com a superconcentração do poder e riqueza acompanhada de estrutura setorial e regional extremamente heterogênea. A longa presença de regimes autoritários concomitante com a centralização estatal havia produzido uma vigorosa e selvagem expansão capitalista, com ampla marginalização social e registro de atores políticos inconstantes, fragmentados e desestruturados no conjunto da sociedade, sobretudo na representação dos segmentos vulneráveis (HENRIQUES, 1999; MARICATO, 1996).

A segunda característica assentava-se à burguesia industrial que, apesar de estar desde a segunda metade da década de 1950 no comando do processo de acumulação capitalista no Brasil, se mantinha intimamente associada ao Estado. Embora tivesse nascido embalada por parceiros da aristocracia cafeeira no último quartel do século XIX, emergiu mesmo à principal fração no interior da classe dominante 
com o fim do ciclo primário exportador e a ascensão imediata do Estado desenvolvimentista desde 1930.

Mas para subordinar o conjunto das forças produtivas precisou articular-se com o capital industrial externo e o avanço estatal. Isso porque foi pelas mãos do Estado desenvolvimentista que a burguesia industrial encontrou o principal apoio de poder e competição, ancorado, em geral, a subsídios e incentivos públicos aos investimentos e à proteção concorrencial.

Por outro lado, a muleta do Estado que poderia ter sido parcial e provisória se tornou plena e permanente, transformou-se numa das principais características da industrialização tardia no Brasil. O comportamento defensivo-especulativo e de aversão ao risco, especialmente nos momentos de crise dinâmica, ajuda a entender os limites financeiros e tecnológicos do capital industrial no país (LESSA; DAIN, 1983; FIORI, 2003).

Por conta disso, a tendência a desequilíbrios macroeconômicos, à inflação maior e ao excedente de força de trabalho guarda relação direta com o perfil do desenvolvimentismo antirreformista que se mostrou viável nos momentos históricos de impasses, geralmente trazidos por alternativas liberal-conservadoras e libertárias. Assim, o crescimento econômico conduzido pelas políticas estatais e liderado pelo capital industrial foi rota de fuga para frente toda a vez que a estagnação da renda per capita se apresentava como um problema, pelo menos entre as décadas de 1930 e 1970.

Acontece que a partir dos anos de 1980, o quadro geral de semiestagnação da renda per capita se estabeleceu cada vez mais sólido no Brasil. Com isso, a perspectiva de aproximar-se dos países desenvolvidos passou a ficar ainda mais distante. 
Destaca-se que somente com a industrialização que o país conseguiu interromper a longa marcha que o distinguia da trajetória das economias capitalistas avançadas. Na época da Independência Nacional, em 1822, por exemplo, a renda per capita dos brasileiros equivalia a pouco mais da metade da dos estadunidenses.

Gráfico 01 - Evolução da relação entre a renda por habitante do Brasil e a dos Estados Unidos em anos selecionados (em \%)

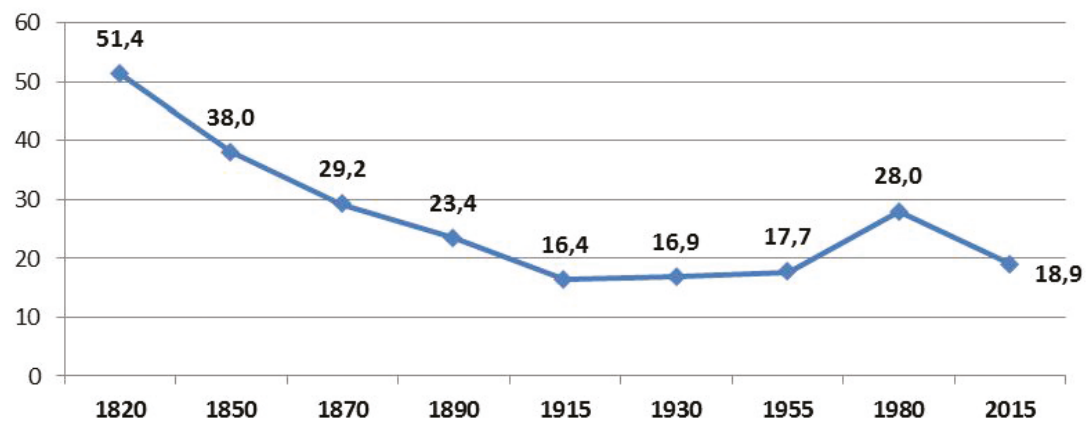

Fonte: Maddison (201 1), FMI (elaboração própria).

Pelo padrão retardatário de industrialização nos Estados Unidos, a sua renda per capita disparou rapidamente desde o começo do século XIX. Por conta disso, a renda per capita dos brasileiros ficou cada vez mais para trás, somente estancada com a transição para a sociedade urbana e industrial desde a década de 1930.

Com a adoção do projeto de industrialização, ainda que tardia, a renda per capita dos brasileiros cresceu acima da dos estadunidenses, sendo de 4,7\% entre 1930 e 1955 e de quase 60\% entre 1955 e 1980. A partir daí, o movimento de semiestagnação da renda per capita tomou conta do país e tornou novamente decrescente em relação com a dos estadunidenses, cuja queda alcança quase 1/3 entre os anos de 1980 e 2015. 
Interessante notar também que a permanência atual do quadro geral de semiestagnação na renda per capita coincide com o processo de desindustrialização nacional. Essa constatação, contudo, destoa do ciclo da industrialização tardia que nada teve de espontâneo, pois foi resultado de luta intensa de uma maioria política forjada na perspectiva de que era a condição imprescindível para a prosperidade da riqueza, a estabilidade da economia e a grandeza nacional (LUZ, 1978; SUZIGAN, 1986; BONELLI, 1995).

Isso porque a prevalência do projeto do livre cambismo, herdeiro do padrão de hegemonia inglesa durante o Império e (1822 - 1889) e a República Velha (1889 - 1930), não havia se mostrado capaz de conduzir a sociedade ao padrão civilizatório superior. Somente a experiência industrializante dos anos de 1930 e 1970 apresentou possibilidades de melhor enfrentar a condição instaurada pelo subdesenvolvimento, o que pressupôs inédita ação articulada do Estado desenvolvimentista em associação com a Ordem Econômica Mundial hegemonizada pelos Estados Unidos (DRAIBE, 1986; IANNI, 1985).

A reversão do curso estadunidense de exercício da hegemonia capitalista a partir dos anos de 1980 teve rebatimentos em todo o mundo, significando no Brasil o gradualismo tanto na desconstituição do Estado desenvolvimentista como no movimento maior da desindustrialização nacional. Em virtude disso que interessa analisar, a seguir, as principais razões do movimento maior da desindustrialização, cujas respostas geradas pelo país se mostraram, desde a segunda da década de 1970, equivocadas.

Ressalta-se, inicialmente, a dupla raiz do antiestatismo que voltou a se manifestar a partir da década de 1970 em conjunto com a emergência do movimento político em defesa da redemocratização nacional. Pelos empresários situados no centro geográfico mais 
importante da industrialização nacional que reapareceram posições contrárias ao Estado desenvolvimentista, cujo avanço foi inquestionável no penúltimo governo militar (1974-1979) através do Plano Nacional de Desenvolvimento (PND).

Na sequência, destaca-se o registro da própria desestatização presente no programa de ajuste exportador que foi aplicado para estancar a contundente crise da dívida externa que abateu o Brasil entre os anos de 1981 e 1983. O autoritarismo no último governo militar permitiu estabelecer um caminho sem saída para o retorno do crescimento econômico sustentável, o que comprometeu ainda mais a manutenção do projeto de industrialização nacional.

Com a aprovação da Constituição Federal em 1988, responsável pela primeira vez na garantia de avanços nos direitos sociais ao conjunto dos brasileiros, a reação da equipe econômica do presidente Sarney foi a de que o país passaria a se tornar ingovernável. Naquele momento, a senha de que o Estado desenvolvimentista perdia virtudes e seria visto como marajá esbanjador de recursos, conforme a expressão adotada por Collor de Mello em 1989 na sua campanha vitoriosa durante a primeira eleição presidencial após o Golpe Militar em 1964.

Apesar do seu impedimento após dois anos do início de gestão, o programa de reformas neoliberais de Collor de Mello teve continuidade nos dois mandatos seguidos do presidente Fernando Henrique Cardoso (1995 - 2002). Neste sentido que o aprofundamento da desconstituição do Estado desenvolvimentista por políticas liberalizantes ao longo da década de 1990 inseriu passiva e subordinadamente o país à globalização financeira e desindustrializante.

A interrupção dos governos neoliberais a partir de 2003 não se mostrou, todavia, suficiente para reorganizar o Estado em novas bases e assim instaurar um conjunto de políticas capazes de levar o Brasil à 
reindustrialização. O pragmatismo da política econômica possibilitou gerar robustos e inegáveis avanços sociais e econômicos ao conjunto do país, sem romper com a trajetória de semiestagnação da renda per capita de longa duração restabelecida com a crise de dimensão global desde 2008, conforme apresentado na sequência.

\section{O passado como projeto de industrialização dos militares e a reação da burguesia industrial na década de 1970}

Os anos de 1970 constituem referência basilar na constatação a respeito da transformação significativa do padrão de acumulação capitalista sob a hegemonia dos Estados Unidos. Até então, a expansão produtiva do american way of life em plena Guerra Fria havia garantido cerca de três décadas de excepcional avanço das economias capitalistas no mundo.

Em 1973, não apenas os Estados Unidos abandonaram o padrão monetário internacional assentado na estabilidade e equivalência do dólar ao ouro como explodiu a crise de dimensão mundial derivada do primeiro choque do petróleo acompanhado pela elevação dos preços das commodities. Diante da recessão e a desaceleração generalizada nas economias ricas, com elevação da inflação e desemprego, as políticas keynesianas anteriormente dominantes na sustentação da demanda agregada perderam eficácia e ganhou cada vez mais sentido o padrão de acumulação apoiado pela financeirização internacionalizada do capital (BRAGA, 2000; CHESNAIS, 1995; TAVARES, 1985). 
Com isso, a composição dos investimentos diretos do exterior sofreram gradualmente duas modificações importantes. Uma primeira modificação decorreu do deslocamento de parte das atividades produtivas das empresas e famílias para fluxos internacionalizados induzidos por aplicações financeiras e especulativas nos mercados nacionais cada vez mais desregulados e dominados por altas taxas de juros.

De imediato, a concentração dos fluxos de capitais nos países capitalistas avançados, que seguiram a orientação do Banco Central dos Estados Unidos de elevar a taxa de juros. Entre 1976 e 1980, por exemplo, a taxa de juros nos EUA (Prime-rate) passou de 6\% para 20,2\%, retornando aos $6 \%$ somente em 1992, o que possibilitou aos mesmos países capitalistas avançados aumentar de $50 \%$ para $75 \%$ a recepção dos fluxos de capitais mundiais.

Outra modificação significativa nos investimentos deveu-se à inovação na antiga relação entre as empresas matrizes e filiais industriais para a mais recente definida pelas corporações transnacionais que passaram a operar cada vez mais na forma de rede. A concentração patrimonial para o controle da produção e distribuição fragmentada em várias partes do mundo esvaziou o objetivo da empresa internacionalizada de produzir para o mercado interno local frente à emergência da indústria de dimensão global assentada nas economias submetidas à abertura financeira, produtiva e comercial (GLATTFELDER, 2013; MILBERG; WINKLER, 2013).

Ademais, pelo curso da Terceira Revolução Industrial, a manufatura terminou se modificando substancialmente, com a introdução do paradigma da produção enxuta e da automação flexível, cuja organização do trabalho tornou-se cada vez mais terceirizado (outsourcing). Também cresceu significativamente a participação do complexo da microeletrônica, mecatrônico, novos materiais, 
nanotecnologia e de comunicação e informação na estrutura industrial (COUTINHO, 1992; PORTER, 1986).

Diante de tantas alterações concentradas no quadro produtivo, comercial, laboral e financeiro internacional que se encontrava sob o questionamento da hegemonia estadunidense, o Brasil buscou estabelecer um grande bloco de investimentos de caráter anticíclico. Isso porque após cinco anos de forte crescimento econômico sustentado pela indústria de bens de consumo duráveis e por investimentos públicos, o governo militar lançou em 1974 o segundo Plano Nacional de Desenvolvimento (II PND).

Ao invés do ajuste recessivo adotado na maior parte das economias, o Brasil se propôs a fugir para frente, com ousada programação de investimentos concentrados na indústria de bens de capital e de insumos básicos e financiados com recursos externos. Em alternativa à ortodoxia imposta em países da região como Chile e Argentina que levou imediatamente à desindustrialização precocemente, o II PND consagrou importante reversão cíclica que fortaleceu ainda mais a industrialização tardia.

Mas ao contrário de outras economias que seguiram no mesmo sentido, como a Coréia do Sul, o Brasil buscou ampliar parcela complementar e substitutiva das importações nos insumos básicos, petróleo e bens de capital atrelados ao velho padrão tecnológico da segunda Revolução Industrial. A Coréia do Sul, por exemplo, estabeleceu tanto no seu terceiro (1972 - 1976) como quarto (1977 - 1981) plano quinquenal de desenvolvimento econômico a descentralização geográfica da planta industrial orientada para exportação através dos conglomerados empresariais (Chaebols) e o fortalecimento das indústrias de alta tecnologia e com maior qualificação da mão de obra (máquinas ferramentas, eletrônicos, entre outras). 
A estratégia do regime militar brasileiro era mais simplista, pois acreditava ser possível completar o ciclo da industrialização tardia, por meio da substituição das importações por produção local. Mesmo que obtivesse o êxito inicialmente almejado, o II PND não superaria as dependências tecnológica e financeira com o exterior, o que terminou por se agravar ainda mais com o avanço da Terceira Revolução Industrial (LESSA, 1978; CARNEIRO, 2002; CASTRO; SOUZA, 1985).

Após ter expandido $11,1 \%$ como média anual no período de 1968 a 1973, a economia brasileira cresceu em média 7,1\% entre 1974 e 1980. Apesar do II PND, o ritmo de expansão do PIB brasileiro desacelerou $36 \%$ entre os dois períodos de tempo, enquanto a economia mundial diminuiu em $38 \%$ a taxa de crescimento econômico, uma vez que passou de 5,3\% em 1968-73 para 3,2\% em 1974-80.

Também o II PND não se mostrou suficiente para evitar que o primeiro choque externo do petróleo e das commodities em 1973 se refletisse sobre o nível do custo de vida dos brasileiros. Entre os anos de 1974 e 1980, por exemplo, a taxa média anual de inflação foi de 51,8\% ante $19,5 \%$ entre $1968-73$.

Da mesma forma, o esforço governamental para ampliar a capacidade energética do país por meio de mais investimentos na Petrobrás e novas fontes de energia (Proálcool e energia nuclear) e aumentar as exportações não evitou a ampliação dos déficits na balança comercial. No período do II PND (1974-79), as importações cresceram 192\% e as exportações $146 \%$, o que fez com que o superávit comercial de 7 milhões de dólares em 1973 se transformasse em déficit de US\$ 2,8 bilhões de em 1979, apesar de ter sido de 4,7 bilhões de dólares em 1974. 
Gráfico 02 - Brasil: evolução da relação da dívida externa com o Produto Interno Bruto (PIB) e da variação do PIB e da taxa de inflação (IGP) em anos selecionados (em \%)

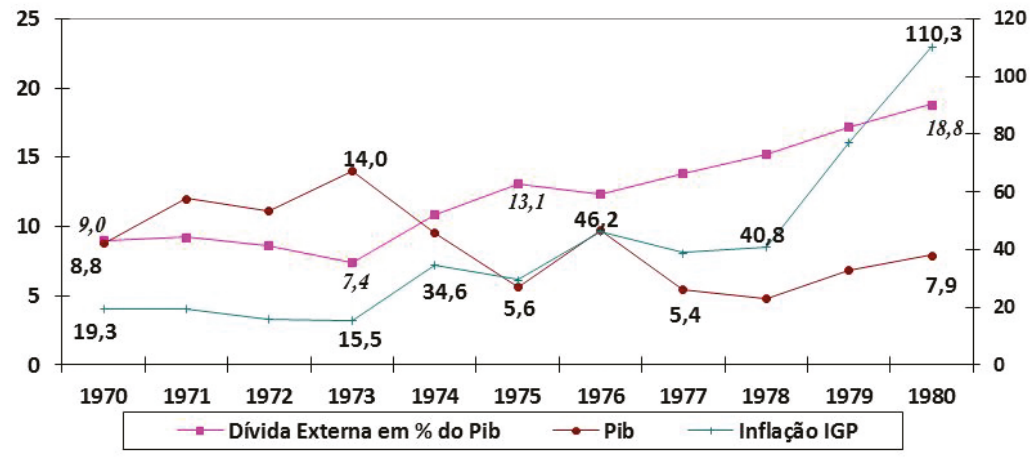

Fonte: IBGE e BACEN (elaboração própria).

O uso de empréstimos externos para financiar parcela importante do II PND terminou impactando a dívida externa, que pulou de 7,4\% do PIB em 1973 para 17,2\% em 1979. Também repercutiu sobre o pagamento dos serviços do endividamento externo que aumentou de 514 milhões de dólares para US\$4,2 bilhões entre 1973 e 1979.

As debilidades do regime militar no estabelecimento de uma política anticíclica eficaz através do II PND estiveram associadas, em grande medida, à fragmentação e apequenamento das empresas privadas nacionais em assumir maior protagonismo no ciclo da industrialização, ao contrário dos conglomerados sul-coreanos. Também acresce a posição da grande empresa estrangeira em se ajustar mais aos interesses definidos preliminarmente pela firma matriz do que a indução da política econômica local.

A reorganização do setor produtivo estatal e o avanço dos investimentos públicos foram importantes, todavia voltados a construir pontes com a industrialização do passado e não com o futuro evidenciado pela emergência da terceira Revolução Industrial. Na sequência, 
a utilização de empréstimos externos para financiar o reforço industrial substitutivo de importação apontou equívocos diante do gigantismo do endividamento externo e das dificuldades do setor produtivo orientado para as exportações.

Diante disso merece atenção o fato de que o II PND foi efetivo em apenas dois anos (1974-76) uma vez que a partir de 1977 sofreu os efeitos decorrentes da adoção de uma política econômica contracionista. Adicionado à saída de Severo Gomes, ministro da Indústria e Comércio do Governo Geisel, coincide o conjunto de críticas empresariais ainda que tímidas em relação à atuação do Estado.

Em alguma medida, a própria imprensa, ainda que censurada, explorou o sentido estatizante do II PND, como revelou a revista Visão e o jornal Estado de São Paulo a partir da segunda metade da década de 1970. Inicialmente, a insatisfação em relação à denominada excessiva intervenção estatal, para na sequência reclamar do protagonismo das empresas estatais.

Tem início, assim, a Campanha Antiestatização impulsionada por parcela de empresários do setor financeiro e comercial e da mídia liberal, sem contar, contudo, com vozes destoantes no meio industrial. A defesa de autonomia empresarial frente à maior centralização do Estado ganhou destaque midiático, embora a insatisfação mais ampla decorresse da desaceleração econômica interna e externa e do ambiente de autoritarismo (CRUZ, 1995; DINIZ; LIMA, 1987; BRESSER PEREIRA, 1981; MELLO; BELLUZZO, 1983).

Mesmo assim torna-se insustentável imaginar que houvesse um pensamento empresarial convergente, sem considerar os diferentes setores de atividades, regiões do país, origem do capital, tamanho do estabelecimento, entre outros. O emblema da antiestatização enquanto campanha pouco mobilizou o conjunto do empresariado, não 
obstante a rigidez do regime militar na determinação (Conselho Interministerial de Preços - CIP) e monitoramento dos preços (Superintendência Nacional de Abastecimento - Sunab) e no uso das 254 empresas estatais, sendo 121 (48\%) delas foram constituídas somente na década de 1970 (RODRIGUES, 1990).

A defesa da desestatização na economia brasileira encontrou obstáculos às várias benesses do Estado, como a reserva de mercado nas compras públicas às empresas privadas nacionais e aos subsídios, isenções fiscais e creditícios. O sentimento empresarial de ambiguidade em relação ao Estado ocorria frente à presença de bancos públicos como o BNDE que era fundamental para o financiamento da industrialização.

O pragmatismo da burguesia industrial parece inegável ao perceber que diante das mudanças na economia mundial na década de 1970, a ação do Estado por meio do II PND atingia esferas necessárias e complementares da economia, sem competir com os seus interesses. Não houve revisão liberal dos industriais, ainda que as críticas ao estatismo coincidissem com o autoritarismo militar na fixação de preços e no engessamento das decisões de mercado.

Mas concomitante com setores progressistas e liberais-democráticos da sociedade brasileira, o ano de 1977 demarcou uma nova movimentação de parte do empresariado, reivindicando o fim do regime de exceção. Adiciona-se a isso, o apoio a Conferência dos Bispos do Brasil e a recuperação dos movimentos estudantil, sindical e de habitação popular. 


\section{A submissão do ajuste exportador à crise da dívida externa na transição democrática da década de 1980}

Durante o ciclo da industrialização nacional ocorrido entre as décadas de 1930 e 1970, o Brasil registrou uma das maiores taxas de expansão econômica do mundo. A partir dos anos de 1980, contudo, a trajetória de semiestagnação da renda per capita passou a predominar, esvaziando o eixo de expansão do capital industrial e sua capacidade de subordinar as demais frações das forças produtivas.

Por conta disso, interessa compreender o que teria acontecido, especialmente na década de 1980, que levou à inflexão no projeto de industrialização nacional. Não obstante um conjunto de políticas econômicas de ajuste implementadas desse então, o país jamais conseguiu retomar sustentadamente ao processo de acumulação de capital comparável ao período imediatamente anterior.

Ao aceitar subordinadamente a proposição de "reformas estruturais" estabelecida pelo Fundo Monetário Internacional, a economia nacional se afastou da necessária transformação tecnológica, distanciando-se da condição de soberania para se integrar à nova reconfiguração capitalista demarcada pela globalização financeira. A contraposição com o leste asiático tornou-se inexorável por ajudar a entender o porquê das respostas dos diversos governos brasileiros indicarem equívocos ao enfrentamento da desindustrialização nacional.

Nesse sentido, a crise da dívida externa, bem como a resposta gerada pelo ajuste exportador logo no início da década de 1980, concentram as razões principais para o descompromisso com o ciclo da industrialização nacional. A Coréia do Sul, que registrou em 1983, por 
exemplo, uma dívida externa equivalente a 53,6\% do seu Produto Interno Bruto, conseguiu manter sem interrupção o seu projeto de industrialização nacional, ao contrário do Brasil que na época (29,5\% do PIB) tinha uma das menores relações dívida externa/PIB (CRUZ, 1999; BELLUZZO; ALMEIDA, 2002; AGHEVLI; MÁRQUEZ-DUARTE, 1995).

Diante do colapso no padrão de financiamento externo das economias nacionais, a capacidade de investimento e coordenação do Estado foi estrangulada no Brasil, mas não na Coréia do Sul que conseguiu, por exemplo, manter em novas bases o esquema anterior de financiamento estrangeiro. Isso tem a ver com distintos encaminhamentos governamentais em relação à crise da dívida externa no início dos anos de 1980.

Por optar pela estatização da dívida externa, o Brasil comprometeu sensivelmente a capacidade de intervenção do Estado, ao contrário da experiência da Coréia do Sul que privatizou o endividamento externo e manteve intensa ação estatal de apoio ao setor privado orientado à superação do débito internacional. Apesar de ter 4/5 de sua dívida externa garantida pelo governo, a maior parcela dela foi assumida pelo setor privado, especialmente os grandes complexos econômicos (Chaebols) que participaram da privatização dos bancos endividados entre 1981 e 1983.

Em 1986, por exemplo, menos de 1/3 do estoque da dívida externa estava sob a responsabilidade do setor público coreano, enquanto em 1976 atingia a quase $45 \%$ do total. Em dez anos (1976 - 86), a participação do Estado no estoque da dívida externa foi reduzida em 28,3\%.

No mesmo período de tempo, o setor público brasileiro aumentou a sua participação relativa na dívida externa total em $49,6 \%$. Isso porque o Estado, que respondia por menos de $58 \%$ do total do endividamento externo em 1976, elevou a sua participação relativa para 
$85,6 \%$ em 1986. Se considerado o ano de 1989, por exemplo, a parte do Estado no total da dívida externa era de $90,1 \%$, ao passo que em 1972 mal alcançava $1 / 4$ do total do endividamento do exterior.

Gráfico 03 - Evolução da participação do setor público no total da dívida externa no Brasil e na Coréia do Sul em anos selecionados (em \%)

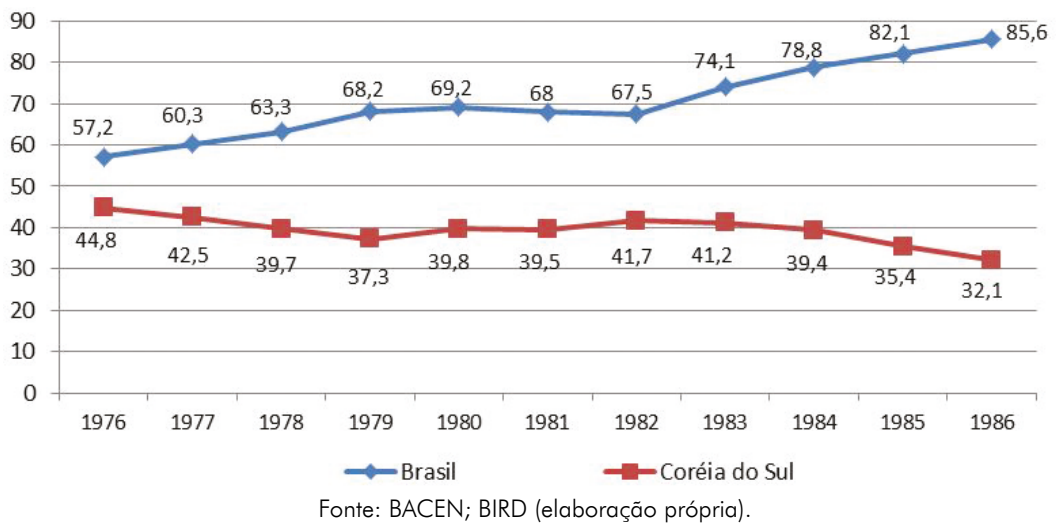

Além disso, a Coréia aproveitou-se da crise da dívida externa para realizar uma importante reforma financeira. Concomitante com a privatização bancária houve a ampliação na quantidade de bancos de dimensão nacional em parceria com o capital estrangeiro e liberação financeira para instituições não bancárias, o que melhorou a intermediação financeira sem desqualificar o Estado enquanto emprestador em última instância.

Por estar na órbita de influência do Japão, a economia sul-coreana encontrou alternativa viável à restrição externa proveniente dos bancos estadunidenses e europeus. Diante de novas fontes de financiamento externo, a Coreia conseguiu dar sequência à sua industrialização, diferentemente do Brasil que se manteve submetido à influência restritiva dos bancos nos Estados Unidos e na Europa. 
Assim, a economia brasileira permaneceu por uma década sem acesso a novos recursos externos não voluntários. Somente por meio de acordos com o Fundo Monetário Internacional (FMI) que entraram recursos externos no Brasil, mesmo assim para atender aos compromissos do endividamento e em respostas às cartas de intensão assumidas pelo país e que mantinham a economia nacional em ambiente de semiestagnação.

Com a adoção do programa de ajuste exportador conduzido pelo FMI, o Brasil produziu a sua primeira recessão econômica desde 1929 com a perspectiva de reorganizar a economia em novas bases. Para isso, o último governo militar (1980-85) esperava reorientar o sistema produtivo para o mercado externo, produzindo saldo comercial estrutural a serviço do pagamento da dívida externa.

O choque exportador provocou não apenas a reorientação profunda da política econômica, como consequências extremamente desfavoráveis ao país. De um lado, o mercado interno terminou sendo substituído pelo mercado externo enquanto fonte do dinamismo econômico nacional.

Mas muito mais que aumentar as exportações, que registraram acréscimo de 27,4\% entre 1980 e 1985, assistiu-se justamente à considerável queda das importações em $43 \%$ no mesmo período de tempo. Com isso, o saldo comercial produzido pelas políticas de ajuste do FMI para o pagamento dos serviços da dívida externa contribuiu para tornar a economia brasileira numa das mais fechadas do mundo.

Ao final da década de 1980, por exemplo, o coeficiente de importação equivalia a apenas $4 \%$ do PIB. Como resultado, o Brasil distanciou-se do processo de modernização e inovação em curso nas economias capitalistas avançadas, tendo de conviver internamente com 
elevadas margens de lucros impostas por empresas sem maior competição externa e afastadas do salto da terceira Revolução Industrial.

Gráfico 04 - Brasil: evolução do saldo da balança comercial, das exportações e das importações em anos selecionados (em US\$ bilhões)

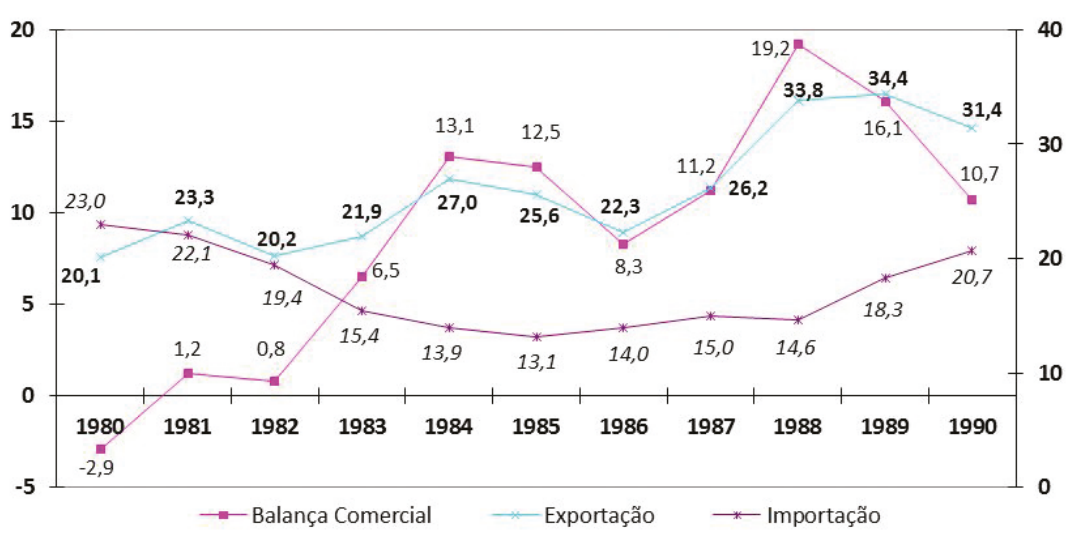

Fonte: IBGE e BACEN (elaboração própria).

De outro lado, a espiral descendente a que foi submetida o país diante das consequências das equivocadas políticas de estatização da dívida externa e de choque exportador em prol do pagamento dos serviços do endividamento exterior. A desmobilização do Estado desenvolvimentista transcorreu diante do desajuste nas contas públicas deixado pelo final do governo militar e demais efeitos inflacionários e descontroles gerais da economia brasileira.

Mesmo com a ascensão indireta do primeiro governo civil entre 1985 e 1990, a economia brasileira não retornou ao crescimento econômico sustentado, tendo permanecido submissa à restrição externa de recursos internacionais e ao pagamento dos serviços do endividamento com o exterior. Enquanto a economia nacional variou em média 2,3\% ao ano entre 1981 e 1987, a Coreia do Sul teve o seu PIB 
aumentado em $8,8 \%$ ao ano em média no mesmo período de tempo. Entre 1971 e 1980, o Brasil registrou crescimento médio anual do PIB de $8,7 \%$ e a Coreia do Sul de $8,3 \%$.

Gráfico 05 - Brasil: evolução da relação do investimento e do custo da dívida externa com o Produto Interno Bruto (PIB) e das taxas de inflação em anos selecionados (em \%)

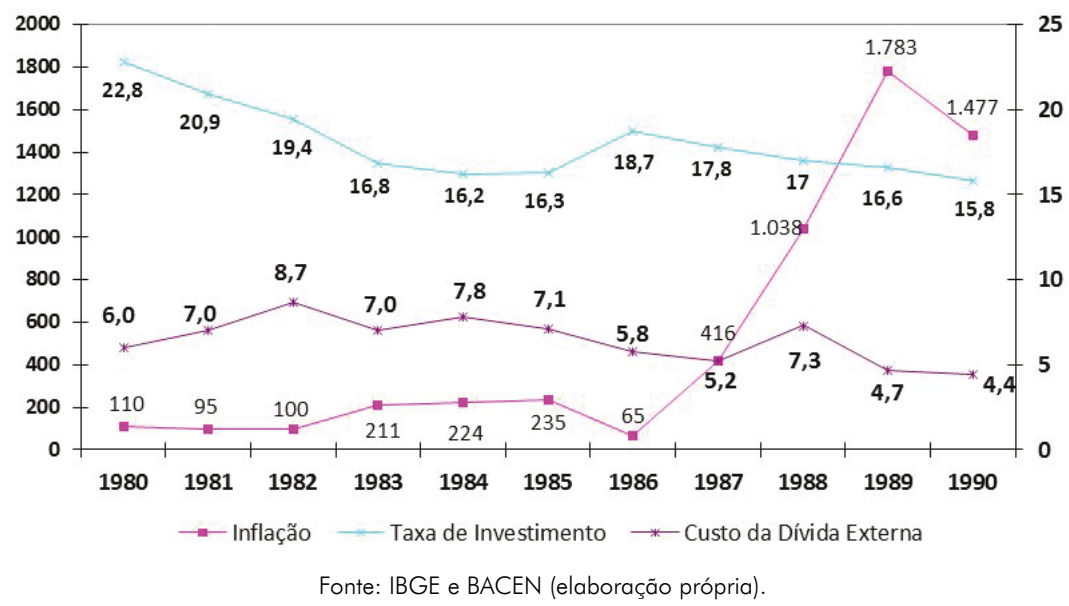

O comportamento desestimulante dos investimentos foi outra consequência negativa do abandono do projeto de industrialização nacional. Entre 1980 e 1990, por exemplo, a taxa de investimento caiu $31 \%$, ao passo que o pagamento dos serviços da dívida externa representou $6,7 \%$ do PIB em media ao ano, feito por transferências ao exterior.

Ainda no âmbito das consequências negativas das políticas de ajuste exportador, cumpre mencionar o problema da inflação. A internalização dos custos de estimular as exportações e contrair as importações, por meio da desvalorização cambial e uma diversidade de benefícios aos exportadores, a taxa de inflação saltou de $110 \%$ no ano 
de 1980 para $1.783 \%$ em 1989. No mesmo período de tempo, a inflação na Coreia do Sul declinou de 28,7\% para 5,1\% ao ano.

Resumidamente, constata-se como a crise da dívida externa e as mudanças introduzidas na política econômica ao longo da década de 1980 levaram o Brasil a uma significativa recessão e ao grave problema das altas taxa de inflação, o que o retirou da trajetória anterior da industrialização estimulada pela expansão do seu mercado interno.

De parte da Coréia do Sul que conviveu com a mesma crise da dívida externa, as respostas governamentais foram noutro sentido. Ao privatizar a dívida e desviar-se do receituário do FMI, registrou leve e pontual recessão superada por importantes medidas governamentais de ampliação da estrutura produtiva conduzida pelo capital industrial.

Mas no Brasil, o destampar da nova marcha de semiestagnação da renda per capita, foi espremido por críticas ao Estado desenvolvimentista, mesmo que pontuais e em alguns segmentos empresariais. O uso das empresas estatais a serviço do ajuste exportador deslocou o compromisso maior com a rentabilidade, assim com o papel do BNDES que atuava como uma espécie de pronto socorro das empresas falidas.

Também ganhou expressão a prevalência dos subsídios e demais privilégios financiados com recursos públicos que por se manter além do prazo conveniente, mostrou-se pouco eficiente no longo prazo. Ainda que favorável aos subsídios e proteção à empresa, uma parcela dos empresários reconhecia que a sua generalização deixava de ser eficaz, assim como a proteção a setores que não o seu, poderia promover déficit público e inflação.

Neste sentido, a manifestação crítica ao Estado desenvolvimentista assumiu mais rapidamente a defesa da menor burocracia e privatização de empresas estatais no contexto de crise da dívida externa e disputa 
cada vez mais acirrada por benefícios públicos por parte do setor privado. Ao mesmo tempo, o autoritarismo do governo militar e suas práticas casuísticas e assistências foi engrossando o caldo empresarial em favor da retomada do regime democrático e enxugamento estatal.

A instalação do governo da Nova República entre 1985 e 1990 representou mudanças importantes na atuação estatal, embora insuficientes para retirar a economia das condições gerais herdadas da ditadura militar. Os vários planos de estabilização econômica fracassaram, assim como a semiestagnação seguiu intocável, sendo as exportações e a especulação financeira em torno do endividamento do Estado, as melhores possibilidades de ganhos econômicos dos empresários.

O êxito político da Constituição Federal de 1988 configurou as bases do regime democrático brasileiro, sem que houvesse a recuperação sustentada do crescimento econômico. Os avanços dos direitos sociais cobraram do Estado a reorganização e a ampliação dos recursos no interior do fundo público, o que fortaleceu de imediato a reação convergente do pensamento liberal autoritário e democrata anteriormente separado no regime militar.

\section{A subordinação da estabilidade monetária à inserção passiva na globalização financeira da década de 1990}

A guinada neoliberal nos anos de 1990 foi provocada ao final do governo da Nova República, quando a equipe econômica do presidente Sarney expressou publicamente que o país se tornara ingovernável com a aprovação da nova Constituição Federal em 1988. A inscrição constitucional de avanços nos direitos sociais, na descentralização do 
Estado e na democratização da participação nas políticas públicas colocou em xeque a herança da ditadura militar de exclusão social, centralização estatal e autoritarismo governamental.

Ao mesmo tempo ficou exposta à necessidade de fazer com que o Estado funcionasse mais efetiva e eficientemente no cumprimento de objetivos da regulação, política industrial, seguridade social e do bem-estar em geral. Isso seria tarefa fundamental para uma reforma estatal, posto que os mercados não substituiriam o papel do Estado e vice versa, conforme destacou o documento Esperança e Mudança do PMDB contendo as proposições reformistas para o ciclo político da Nova República.

O que se notou, contudo, foi a emergência da contestação liberal-conservadora que incorporou a defesa das políticas do Consenso de Washington, visando o Estado mínimo e não intervencionista. Nesta perspectiva tornou-se subentendido que os mercados eram melhores que os governos, o que exigia, por consequência, a redução do Estado para o fortalecimento da iniciativa privada, confundindo propositadamente a intervenção pública com autoritarismo.

Como a agenda de fazer com que o Estado funcionasse mais efetiva e eficientemente não fez parte da campanha eleitoral vitoriosa do presidente Fernando Collor de Mello em 1989, ademais de ser muito complicada, passou a vigorar a tarefa de reduzir o tamanho do setor público. A partir daí, o sentido da desconstituição do Estado desenvolvimentista e a liberalização da economia à globalização financeira passou a ser perseguida continuamente, sobretudo entre os anos de 1990 e 2002.

Nesse sentido que o Consenso de Washington se tornou funcional ao primeiro governo brasileiro eleito democraticamente após a Ditadura Militar, uma vez que perseguiu o conjunto simplificado das dez medidas 
orientadoras da política econômica (disciplina fiscal, redução dos gastos públicos, reforma tributária, determinação dos juros pelo mercado, taxa de câmbio dependente igualmente do mercado, liberalização do comércio externo, eliminação das restrições ao investimento direto externo, privatização das empresas estatais, desregulamentação da legislação econômica e do trabalho e regulação da propriedade intelectual). Esse receituário terminou sendo em geral aplicado indistintamente em vários países do mundo, independentemente de serem recomendações práticas mais associadas às economias de capitalismo avançado.

De maneira geral, os países capitalistas de industrialização tardia possuíam governos com mais capital e qualidade de recursos humanos que o setor privado, detendo, por isso mesmo, capacidade superior de ativação das forças dos mercados, como por exemplo, elevar a eficiência e competitividade por meio de políticas públicas. Diante de uma década de experiência do ajuste exportador orientado pelo FMI, o Brasil entrou nos anos de 1990 com restrição significativa à importação e contido estímulo à eficiência e modernização do padrão de competitividade dos mercados.

Em função disso que, naquela oportunidade, o estímulo à competição nos mercados através de políticas públicas adequadas, ao invés da simples adoção de medidas voltadas à redução do papel do Estado e à privatização do setor público estatal, reunia grande importância. A China, por exemplo, que não adotou o Consenso de Washington na plenitude conseguiu ampliar consideravelmente a abrangência e modernização da competição sem privatizar estatais, cujos resultados alcançados se mostraram superiores aos dos países de governos neoliberais.

Enquanto uma parte importante da economia brasileira foi privatizada, os avanços no padrão de competitividade foram pouco relevantes, o que levou à contenção da produção industrial frente à 
abertura comercial e financeira sem critérios adequados. O contraste entre China e Brasil em relação à economia política da privatização e da competição novamente se impôs.

De um lado porque a privatização de antigos monopólios públicos gerou preços finais com elevadas margens de lucro, assim como problemas de corrupção, regulação, entre outros. De outro, a política pública favorável à competição dos mercados gerou o encolhimento de vários setores produtivos e maior internacionalização da economia.

Mas a crença predominante no Brasil foi a de que seria suficiente o governo reduzir o grau de intervenção para que imediata e naturalmente os mercados gerassem o crescimento econômico com alocação eficiente dos recurso disponíveis. O resultado colhido foi diferente, uma vez que as proposições do Consenso de Washington, quando não equivocadas, apresentaram-se incompletas e contraditórias entre si.

Para que os mercados voltassem a funcionar satisfatoriamente não bastaria alcançar a estabilidade monetária, sem a regulação financeira eficiente e políticas adequadas de estímulo à competição, à incorporação tecnologia, ao investimento, entre outras que não ocorreriam naturalmente. A busca do desenvolvimento deveria incluir medidas ausentes do receituário neoliberal, conforme a experiência asiática recente.

O que se verificou foi a queda importante na inflação a partir de 1994, sem que a taxa de investimentos aumentasse. Pelo contrário, os investimentos como proporção do Produto Interno Bruto decresceram na década de 1990.

Em contrapartida, assistiu-se ao incremento considerável do desemprego da força de trabalho. Entre 1990 e 2000, a taxa nacional de desemprego foi multiplicada por duas vezes, pois passou de $4,3 \%$ para 8,6\% do total da População Economicamente Ativa. 
Gráfico 06 - Brasil: evolução das taxas de investimento, de desemprego e da inflação em anos selecionados (em \%)

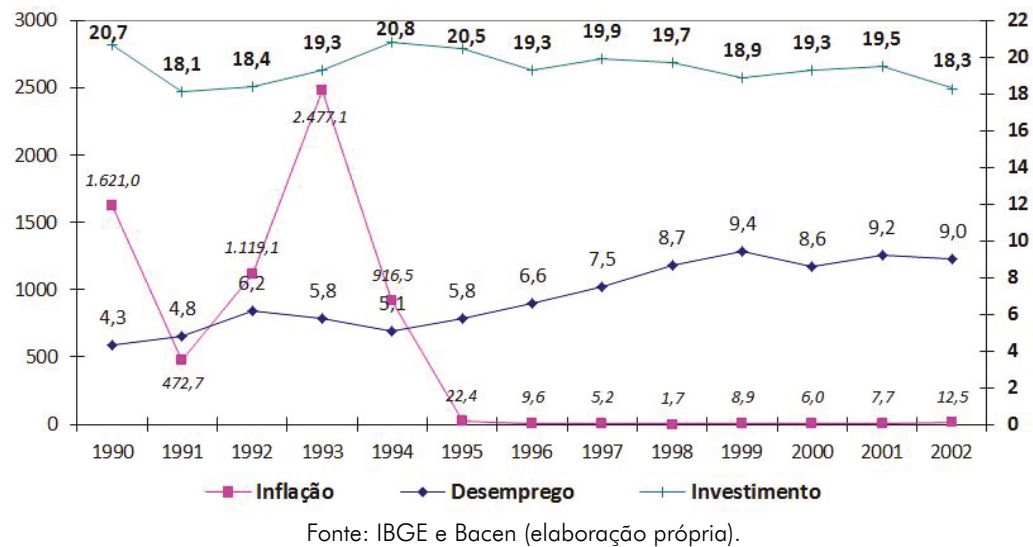

Diferentemente do Brasil, a China partiu do pressuposto de que cada país possui desafios distintos, incapazes de serem tratados por receituários padronizados como o estabelecido pelo Consenso de Washington. Assim, todo o esforço governamental pela estabilização econômica não deveria se distanciar da constante busca pela inovação, o que permitiu manter o curso da industrialização nacional. Entre 1990 e 2002, por exemplo, a expansão média anual do PIB chinês foi de $9,3 \%$, enquanto o do Brasil foi de 1,9\% ao ano.

Sem conseguir elevação da capacidade interna de produção, a política governamental brasileira tratou de estimular as importações para além das exportações. Assim, diante da ampliação efetiva da oferta de bens e serviços na economia brasileira, a estabilidade no nível de preços foi garantida a partir da segunda metade da década de 1990.

Neste sentido, a abertura comercial foi realizada concomitante com diminuição das tarifas alfandegárias e valorização cambial. Por conta do rápido crescimento das importações acima das exportações, o país passou a registrar déficits na balança comercial entre 1995 e 2000. 
Em contrapartida a esta opção governamental de liberalização comercial e financeira, a conta corrente do balanço de pagamentos voltou a manifestar significativo déficit, cada vez mais dependente da entrada do capital externo. Entre os anos de 1991 e 2002, por exemplo, a conta corrente do balanço de pagamentos acumulou déficit de 184 bilhões de dólares.

O desequilíbrio nas transações correntes do balanço de pagamento expandiu-se em virtude dos déficits externos na balança de serviços e de comércio, sobretudo com a implantação do Plano Real. Em 1994, por exemplo, o déficit na conta corrente foi de 1,8 bilhão de dólares, ao passo que, em 1998, alcançou US\$33,4 bilhões e, em 2002, de 7,6 bilhões de dólares.

Gráfico 07 - Brasil: evolução do saldo da Balança Comercial, da Conta Corrente do Balanço de Pagamentos e do Fundo de Investimento Estrangeiro* em anos selecionados (em US\$ bilhões)

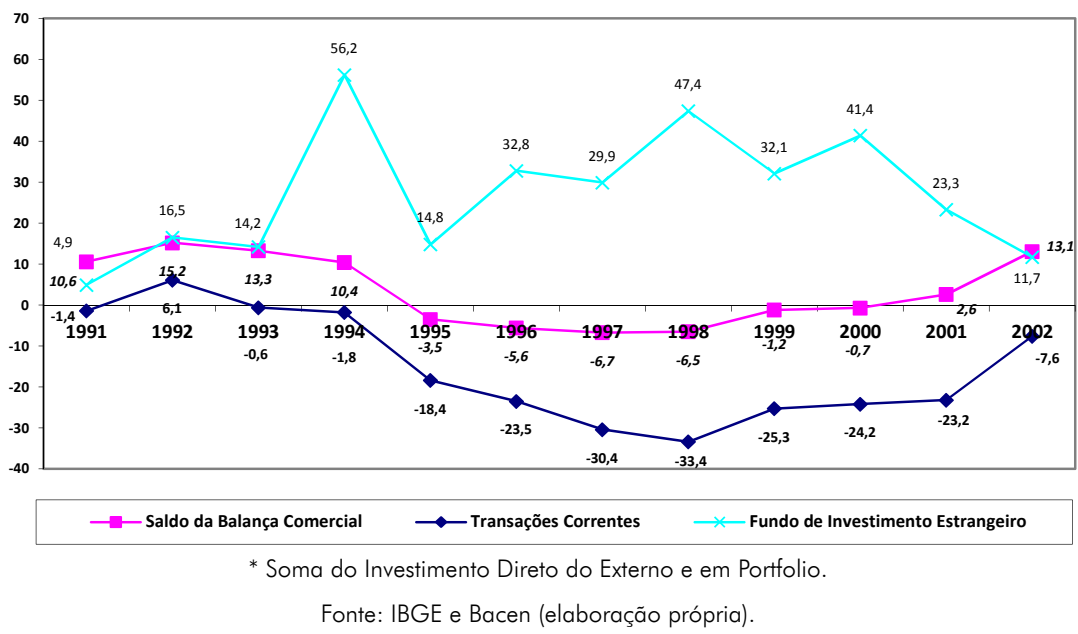

A conta de serviços do balanço de pagamentos cresceu mais por conta das rendas transferidas para o exterior, como remessas de lucros e pagamentos de juros sobre a dívida e o capital especulativo 
(portfólio). Sem acumular reservas externas, os governos neoliberais buscaram estimular o ingresso de capital estrangeiro para fechar o balanço de pagamentos do país, o que tornou a estabilização monetária subordinada à globalização mais financeira do que comercial.

De um lado, a necessidade recorrente de atrair investimentos diretos externos por meio de privatizações das empresas estatais e de subsídios e incentivos tributários (guerra fiscal) para a instalação de novas empresas estrangeiras. De outro lado, a utilização de altas taxas reais de juros como incentivo à atração de capital externo, sobretudo o especulativo (portfolio).

Neste sentido que se percebe a ascensão da taxa real de juros patrocinada pelo Banco Central do Brasil. Durante os governos autoritários, a taxa básica real média anual de juros era negativa, ou seja, abaixo da inflação, ao contrário do que passou a valer especialmente a partir do Plano Real.

Desde a transição para o regime democrático que a taxa de juros se apresentou sempre acima da inflação, o que significou a transferência de renda do setor produtivo para os ativos financeiros. Em outras palavras, o processo de financeirização de riqueza passou a gradualmente substituir o poder do capital industrial de subordinar as demais frações das forças produtivas.

Os governos neoliberais da década de 1990 foram aqueles que patrocinaram as maiores taxas de juros reais. Entre 1995 e 1998, por exemplo, os juros básicos reais médios foram de $22,1 \%$ ao ano, o que se mostrou imbatível frente às expectativas de lucratividade em qualquer atividade econômica legal.

Uma segunda consequência desfavorável do uso recorrente de política monetária restritiva para manter elevada a taxa de juros reais 
no Brasil e assim atrair o ingresso de recursos externos foi a valorização cambial. Com a liberalização da conta de capitais, o ingresso e saída de recursos do país passaram a depender do diferencial da taxa de juros interna em relação à praticada no exterior.

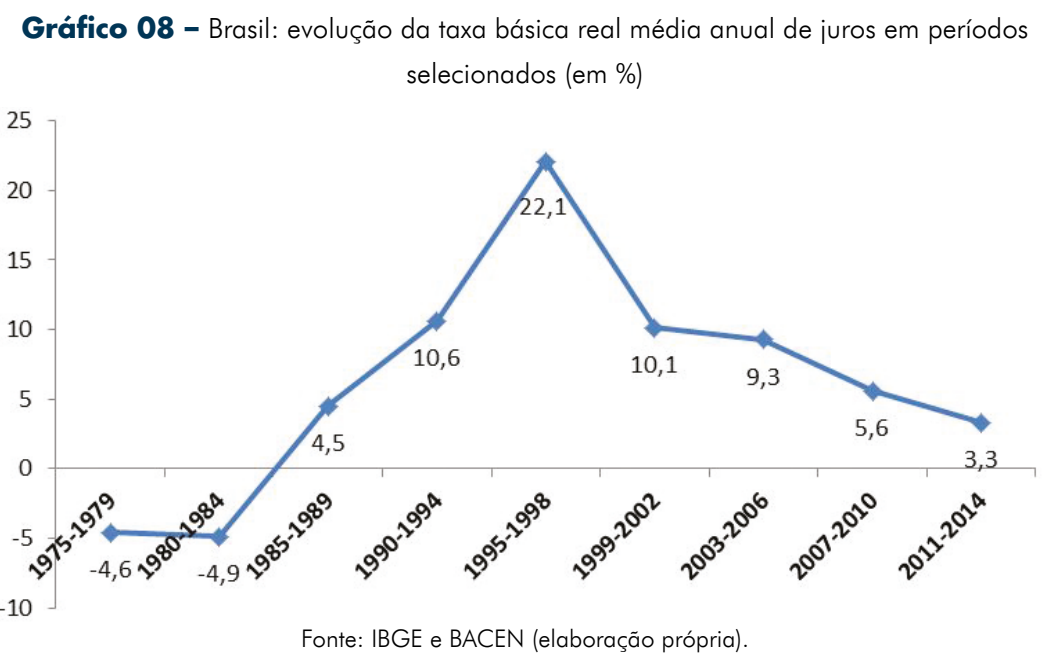

Com juros reais elevados, a atração de capitais estrangeiros tornou-se positiva, sobretudo daquela parte mais especulativa, o que produziu valorização da moeda nacional em relação ao dólar, por exemplo. E quanto maior a valorização cambial, maior o incentivo à aquisição de bens e serviços importados.

Assim, assistiu-se a crescente substituição de mercadorias produzidas no Brasil por importados, sobretudo no setor industrial. A desindustrialização acentuou-se nos anos de 1990 devido à valorização cambial e às altas taxas de juros que desmotivaram continuamente a produção interna.

Por fim, o terceiro efeito negativo da alta taxa de juros praticada no Brasil concentrou-se nas finanças do setor público. Diante do 
estoque da dívida pública, a manutenção da alta taxa real de juros aumentou o custo do seu financiamento pelo governo por meio da maior parte das despesas públicas comprometidas com os gastos financeiros.

Na segunda metade da década de 1990, por exemplo, o Brasil comprometeu com o pagamento dos juros sobre a dívida pública, quantidade de recursos orçamentários equivalente a quase $7 \%$ do Produto Interno Bruto. Essa referência foi 2,4 vezes superior ao registrado antes da implantação do Plano Real.

Pela elevação das despesas públicas financeiras, bem como na área social por força da Constituição Federal de 1988, houve aumento considerável na tributação em geral, mais especialmente nos impostos indiretos que atingiram proporcionalmente os mais os pobres. Dessa forma, a Carga Tributária Bruta cresceu quase dez pontos percentuais em relação ao PIB entre o período de 1985 - 1989 e de 1999 - 2002, pois passou de $24,2 \%$ para $33,1 \%$ do PIB no mesmo período de tempo.

Apesar do apoio dos governos neoliberais no Brasil ao longo da década de 1990, constatado por três vitórias eleitorais sucessivas (1989, 1994 e 1998), os resultados econômicos e sociais não foram positivos, sobretudo em relação à luta pela superação da condição de subdesenvolvimento. A desindustrialização avançou ao mesmo tempo em que vários países da Ásia do Leste conseguiram concentrar a produção manufatureira do mundo, sem adotar o receituário do Consenso de Washington.

O papel do Estado naqueles países tem sido estratégico para o desenvolvimento econômico, especialmente para a industrialização. Por conta disso que a substituição do Estado desenvolvimentista no Brasil por políticas neoliberais desde o final dos anos de 1980 tornouse a antítese do projeto de industrialização nacional verificado entre as décadas de 1930 e 1970. 
Gráfico 09 - Brasil: evolução da Carga Tributária Bruta, do Gasto Social e dos Juros da Dívida pública em períodos selecionados (em \% do PIB)

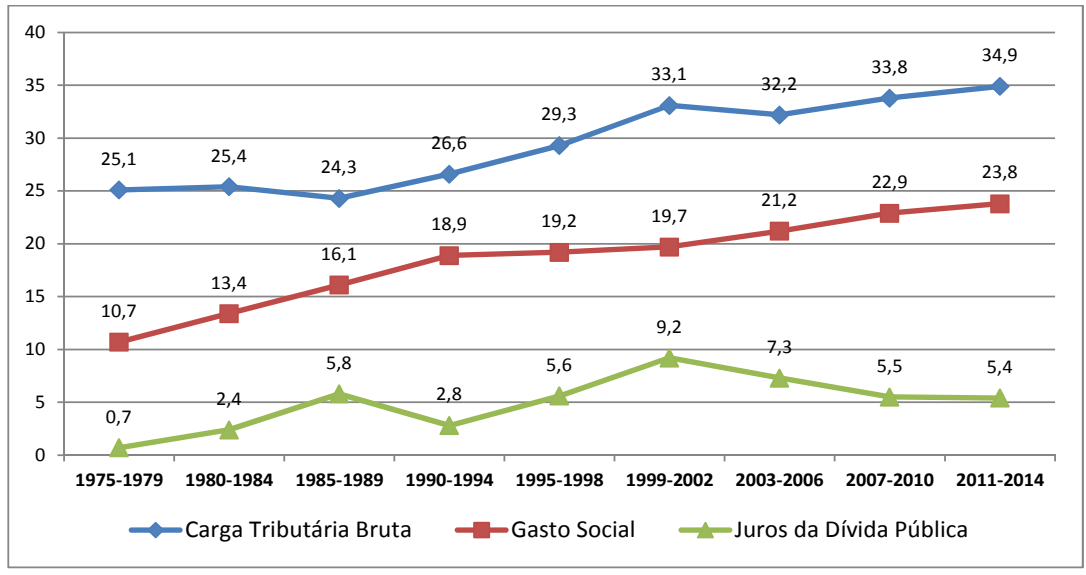

Fonte: IBGE e BACEN (elaboração própria).

Pelo receituário do Consenso de Washington, a dominância financeira passou a ocupar a antiga posição de comando da dinâmica econômica representada pelo capital industrial. A subordinação das forças produtivas ao comportamento dos juros e da valorização cambial conduziu a economia brasileira ao quadro geral da desindustrialização e, por consequência, a semiestagnação da renda per capita.

A força do antiestatismo nos anos de 1990 expressou o movimento liberal conservador que já na transição do autoritarismo para a democracia se insurgiu contra o Estado desenvolvimentista. Guardada a devida proporção, o retorno das teses do livre-cambismo do século XIX trouxe a atualidade para o capitalismo brasileiro de dominância financeira, de desconstrução do Estado desenvolvimentista e de sua contra face, o emagrecimento da burguesia industrial no país. 


\section{O limite do pragmatismo conciliatório da} maioria política dirigente e a crise de dimensão
global dos anos 2000

O discurso idealizado por de Getúlio Vargas, em 1954, cujo destaque foi: "hoje, vocês (trabalhadores) estão com o governo. Amanhã vocês serão o governo" (VARGAS, 1969) encontrou, quase quarenta anos depois, a sua expressão concreta diante da vitória de um operário metalúrgico nas eleições presidenciais de 2002. Naquele momento não significou, todavia, o avanço do socialismo conforme almejado pelo projeto original do Partido dos Trabalhadores, mas o enfrentamento da trajetória de aprofundamento do subdesenvolvimento num capitalismo permeado pela desindustrialização e semiestagnação da renda per capita desde a década de 1980.

De imediato, a irrupção da percepção de mudança que adviria do resultado eleitoral daquela que viria a ser a mais longa experiência de governos de centro esquerda no Brasil. Mas, na sequência, as possibilidades de intervenção concreta diante das realidades externa e interna dadas ao país conduziram à redução das expectativas em torno da combinação exitosa do crescimento econômico com justiça social.

De um lado, o quadro internacional de deslocamento do centro dinâmico para a Ásia em meio aos sinais de enfraquecimento da hegemonia estadunidense. No mesmo sentido, o predomino do papel das corporações transnacionais na condução do processo de inovação tecnológica e indução aos fluxos financeiros, comerciais e produtivos.

Esta realidade externa havia alterado significativamente o perfil dos investimentos, sobretudo aqueles anteriormente orientados à periferia do capitalismo mundial. Pela conformação da nova indústria 
global e os êxitos acumulados até então pela emergência de várias economias asiáticas, as oportunidades da reindustrialização brasileira se tornavam mais complexas.

De outro lado, a herança dos governos neoliberais apontava para a inédita dominação financeira, desconstituição do Estado desenvolvimentista e enfraquecimento da burguesia industrial brasileira. Tudo isso associado ao quadro nacional já conhecido de enorme processo de exclusão social no interior da sociedade.

A passagem por mais de uma década das políticas neoliberais havia enfraquecido e fragmentado atores sociais relevantes, como partidos políticos, sindicatos e associações da sociedade civil, mantendo ainda uma verdadeira massa de marginalizados da atuação política relevante. Ademais, a base social que fundamentou da vitória eleitoral em 2002 era heterogênea e relativamente frágil.

Em virtude disso, três foram as principais possibilidades de encaminhamento governamental a partir de 2003. A primeira seria a de confronto direto com o projeto político originado da realidade liberalconservadora, buscando reconectar-se com o programa das Reformas de Base do governo de João Goulart no início dos anos de 1960 e que havia sido interrompido pelo golpe militar em 1964. Certamente a possibilidade política mais difícil, senão a mais arriscada.

A segunda possibilidade seria a da continuidade acomodativa frente ao projeto neoliberal que se encontrava em curso desde o final dos anos de 1980. Diante dos enormes desafios colocados pela realidade, esta seria a via mais fácil, porém a mais frustrante do ponto de vista político centro-esquerda.

A terceira possibilidade foi a que terminou sendo a escolhida. Simplificadamente, o uso do pragmatismo político para avançar o 
projeto de esquerda no governo a partir do exercício de conciliar simultaneamente no todo, a diversidade fragmentada da sociedade com a viabilidade dos caminhos de menor resistência. Uma verdadeira fuga para frente, cuja retomada do crescimento econômico seria essencial para viabilizar o processo político de ganha-ganha por todos, ainda que mais intenso aos mais pobres.

Gráfico 10 - Brasil: evolução do índice de preços dos bens primários e manufaturados

$$
(\mathrm{Jan} / 1991=100)
$$

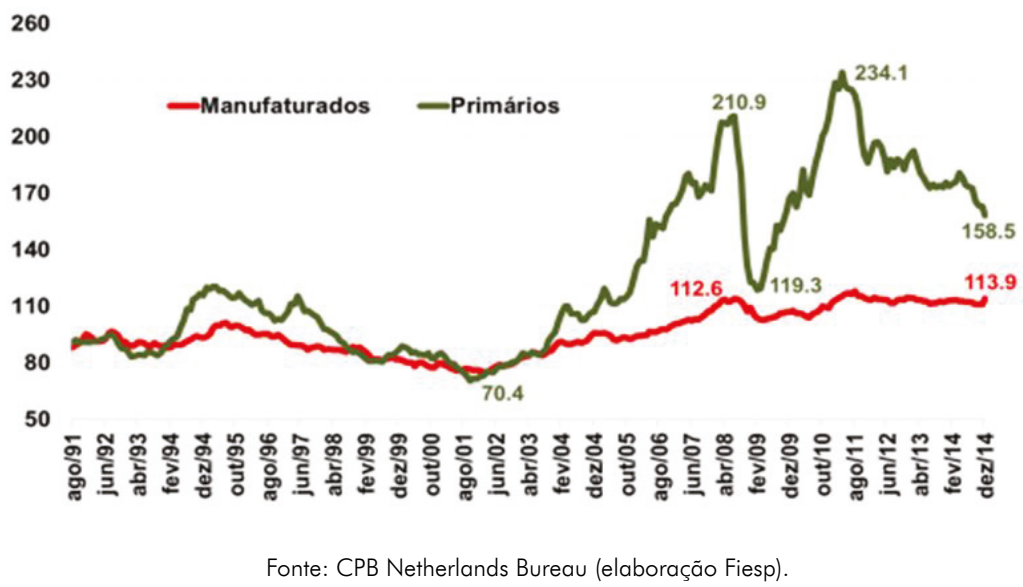

Nesse sentido que o aparecimento do supercíclo de preços dos produtos primários estimulado pela significativa demanda asiática se mostrou extremamente funcional ao curso do exercício do pragmatismo político nos anos 2000. Por um lado, a oportunidade de resolver tanto o problema da dívida externa que o país carregava por 25 anos como o de constituir um fundo com reservas em moeda externa de grande porte para estabilizar o balanço de pagamentos fragilizado desde os anos de 1980. 
Assim, o Brasil assumiu a inédita condição de país credor internacional a partir de 2007, tendo a relação entre a dívida externa líquida e o PIB se tornado negativa, após alcançar o patamar de $37 \%$ em 2002. No mesmo sentido, as reservas externas saltaram de US\$ 16,3 bilhões em 2002 para 374,1 bilhões em 2014.

Por outro lado, a mudança relativa nos preços internos, sobretudo nos industriais, com o avanço da oferta de produtos manufaturados advinda da China. O acirramento na competição no interior da estrutura oligopolizada da indústria global derrubou as margens de lucro de alguns segmentos das empresas no Brasil, compensada, em grande medida, pelo ativismo renovado das políticas públicas do novo governo.

Para tanto, o tripé da política econômica construído na crise do Plano Real, em 1999, terminou sendo mantido, com a prevalência do câmbio valorizado e das altas taxas de juros reais, ainda que decrescentes em relação à década anterior. Pela garantia governamental de cumprimento das metas de inflação, do superávit fiscal e do cambio flutuante, os interesses da dominância financeira permaneceram resguardados por mais tempo, sem entrar em choque direto com as políticas de ativismo de um governo com posição ideológica de centro esquerda.

O encaminhamento de uma via própria para enfrentar a urgência do aprofundamento do subdesenvolvimento gerado pela desindustrialização e estagnação da renda per capita passou pela reinvenção de um novo tipo de capitalismo de Estado. Três dimensões da estratégia de reconstrução do capitalismo de Estado foram exploradas simultânea e articuladamente.

A primeira dimensão inscrita nas ações de recuperação do papel estratégico do Estado para a centralidade do mercado interno na determinação da dinâmica econômica nacional. Ao contrário do preceito neoliberal, o crescimento econômico não se produziria naturalmente 
pela livre força dos mercados, tampouco numa nação de grandiosidade territorial e populacional poderia deixar à margem o comportamento do seu mercado interno aos impulsos da globalização.

Nesse sentido, a recuperação da capacidade do Estado para planejar ações de maior envergadura no médio e longo prazo, bem como coordenar um conjunto de políticas por meio dos bancos públicos federais (BNDES, BB, CEF, BND, Basa) e empresas estatais (Petrobrás, Eletrobrás, entre outras). Da mesma forma, a elevação dos investimentos públicos, sobretudo na infraestrutura e energia, indústria, construção civil e outros setores, ocorreram por meio de planos e programas (Plano de Aceleração Econômica e programas Brasil sem miséria, Minha casa, minha vida, Safra Agrícola, entre outros).

Também as concessões públicas para o setor privado nacional e estrangeiro permitiram financiar as atividades econômicas que até então se encontravam paralisadas. Diante disso, a economia brasileira expandiu ao ritmo médio anual de 3,4\% entre 2003 e 2014, sendo acompanhada praticamente no mesmo ritmo pela produção industrial, ao menos até a crise de dimensão global iniciada em 2008.

Entre 2008 e 2014, por exemplo, a economia nacional cresceu 2,6\% como média anual, enquanto entre 2003 e 2008, havia sido de $4,2 \%$ ao ano. No caso da indústria de transformação, o aumento médio de 3,7\% ocorreu entre 2003 e 2008 ante o decréscimo de 0,3\%, em média anual entre 2008 e 2014.

No caso do emprego na indústria de transformação também se verificou desempenho distinto antes e depois da crise internacional de 2008. De 2003 a 2008, o crescimento do emprego industrial aumentou 2,8\% em média ao ano, enquanto entre 2008 e 2014 foi de $0,7 \%$ ao ano. 
Gráfico 11 - Brasil: evolução dos índices de emprego na indústria de transformação, da produção indústria e do Produto Interno Bruto em anos selecionados $(2001=100)$

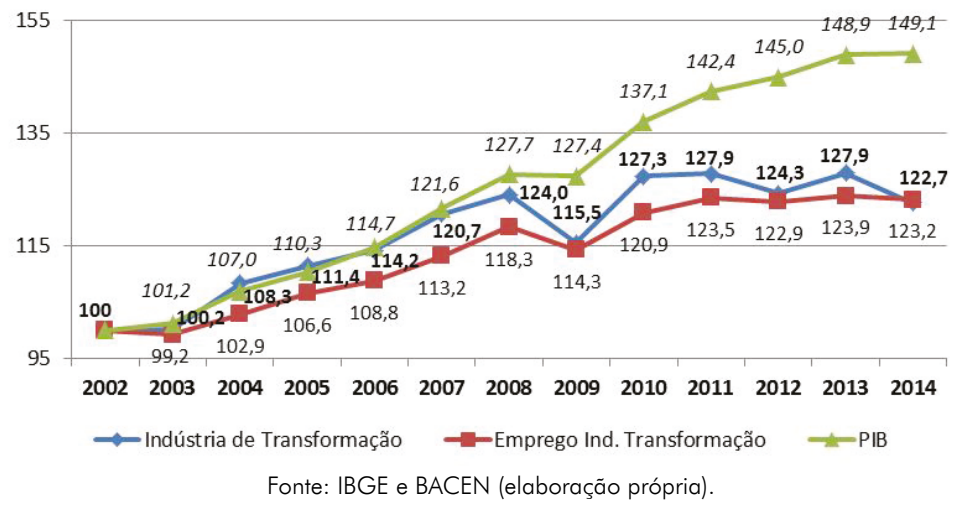

Mesmo sem a expansão industrial, a continuidade no crescimento do PIB após 2008 foi possivelmente consequência da segunda dimensão estratégica adotada de reconstrução do capitalismo de Estado no Brasil. Destaca-se fundamente o conjunto de medidas adotadas com o objetivo da inclusão social, por meio da busca do pleno emprego e da redução das desigualdades, sobretudo na renda do trabalho.

Para isso, a transformação do Estado enquanto indutor principal do movimento maior de ascensão social. O aumento considerável do salário mínimo real protegeu o piso das remunerações dos ocupados, enquanto os programas de transferência de renda alcançaram pela primeira vez a base da pirâmide social, permitindo se afastar da condição de consumidora marginal.

O resultado disso foi a ampla inclusão pelo mercado interno, ampliando as potencialidades de uma sociedade de consumo de massa. Do conjunto do gasto social, quase $2 / 3$ passaram a ser comprometidos com as ações governamentais de transferência de renda ao conjunto da população. 
No caso do consumo de bens e serviços, cuja oferta dependeu do setor privado, houve expansão acelerada, ao contrário da produção de bens e serviços públicos. Exemplo disso foi uma espécie de homogeneização do consumo de celulares, televisores, entre outros bens de consumo duráveis, ao contrário do acesso ao saneamento básico, creche e outros bens e serviços públicos.

De todo o modo, a redução no desemprego seguiu contínua, sem abalo, mesmo com a crise internacional de 2008. A própria taxa de investimento da economia brasileira que cresceu 27,4\% entre 2003 e 2010, decaiu 8,2\% a partir de 2011 , concomitante com a redução sensível do saldo na balança comercial.

Gráfico 12 - Brasil: evolução do saldo da balança comercial (em US\$ bilhões) e das taxas (em \%) de investimento e de desemprego metropolitano em anos selecionados

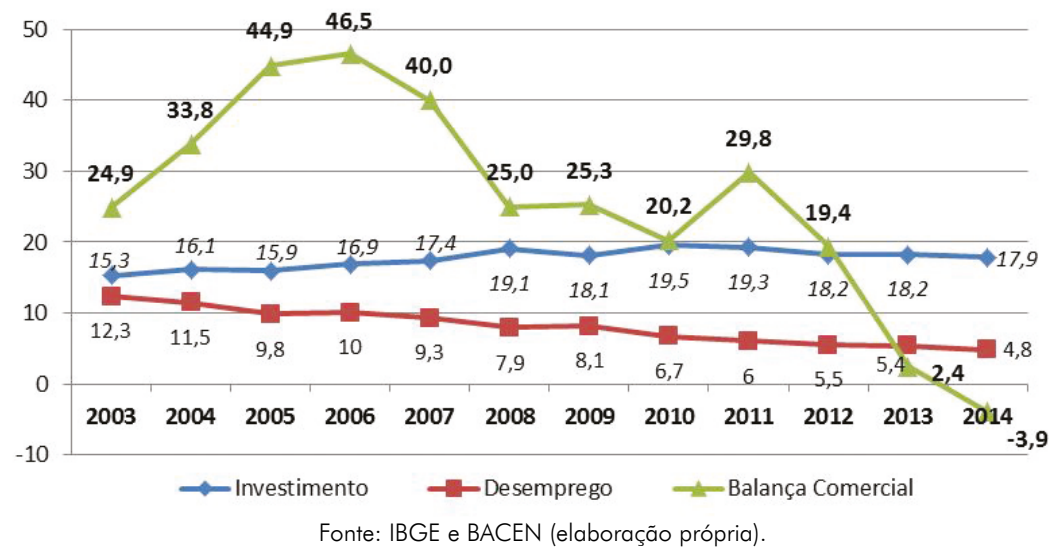

Por fim, a terceira dimensão da estratégia de reconstituição do capitalismo de Estado adotada desde 2003 compreendeu a ação para reconverter a burguesia industrial da situação geral de subordinada à dominância financeira consagrada pelo neoliberalismo. Para fortalecer 
o capital industrial, o uso das políticas governamentais de preferência ao conteúdo nacional nas compras públicas e das empresas estatais.

Ao mesmo tempo, o avanço na política de crédito que permitiu aumentar sua proporção em relação ao PIB de 24,7 \%, em 2003, para 58,9\%, em 2014. Somente o crédito ao setor industrial cresceu 108,7\% no mesmo período de tempo, ao passo que no na construção civil aumentou 553,3\% e 78,6\% no meio rural, o que indicou o papel ativo dos bancos público no financiamento da produção agrícola, construção civil e industrial.

Gráfico 13 - Brasil: evolução da participação relativa da indústria de transformação no Produto Interno Bruto (em \%)

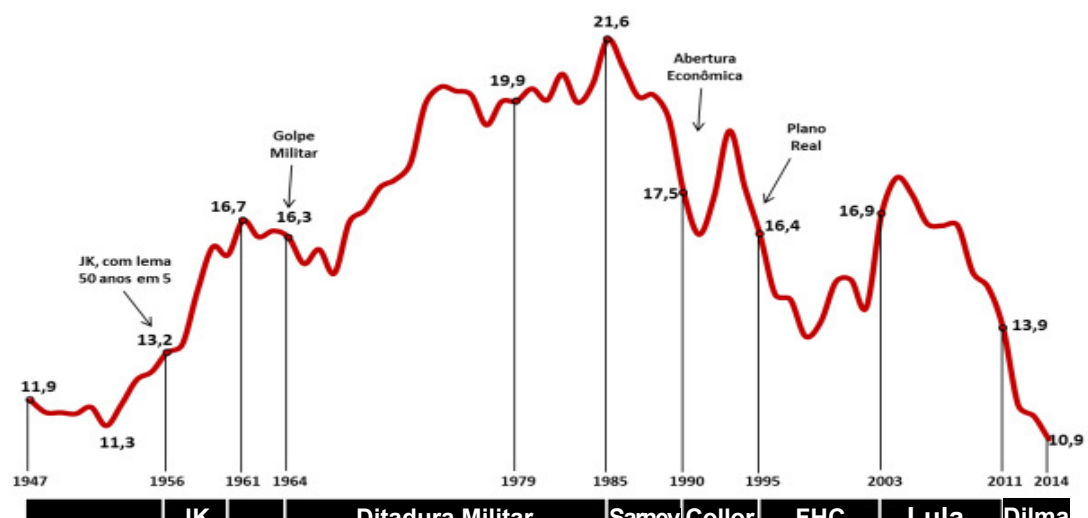

JK

Ditadura Militar

Samey Collor FHC

Lula Dilma

Fonte: Mdic (elaboração de Sarquis, 2011)

Dessa forma, as vendas elevaram-se consideravelmente, como as do complexo automotivo brasileiro que passaram de 1,5 milhão de unidades em 2003 para 3,8 milhões em 2012, reduzido levemente para 3,5 milhões em 2014. No caso das unidades habitacionais disponibilizadas por financiamento conjunto da Caixa Econômica Federal e outras fontes, constata-se a elevação significativa de 194 mil em 2002 para 1,2 milhão em 2014. 
O crescimento do PIB per capita de 2,1\% em média ao ano entre 2003 e 2014 ante à média anual de 0,6\% no período de 1995 e 2002 apontou a superação do quadro anterior de semiestagnação da renda por habitante. Mas isso, todavia, não se mostrou suficiente para retirar o país da situação de desindustrialização.

Não obstante os esforços governamentais, a dominância financeira sobre as frações do capital se manteve ativa, ao mesmo tempo em que o peso relativo da indústria de transformação continuou a cair no total do PIB. Embora houvesse uma breve interrupção na primeira metade da década de 2010, assistiu-se ao esvaziamento industrial mais intenso com a manifestação da crise de dimensão global desde 2008.

Gráfico 14 - Brasil: evolução da composição das exportações (em \%)

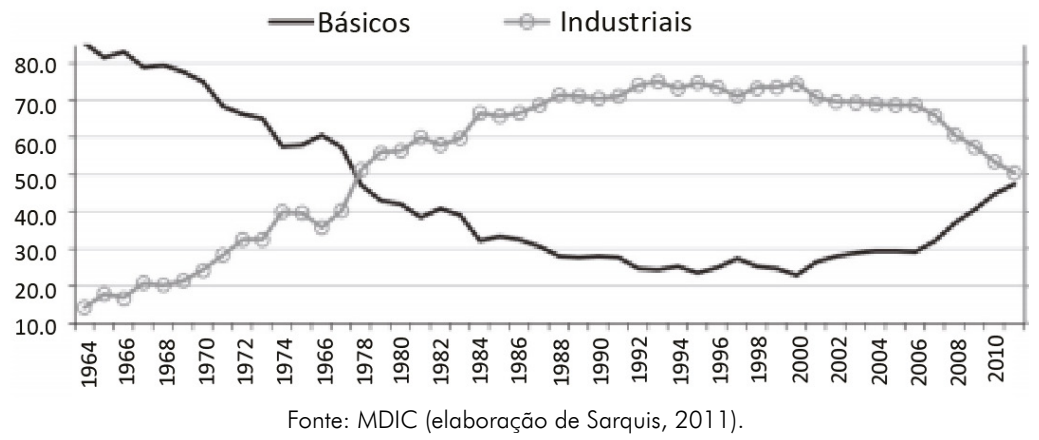

A imutabilidade do tripé da politica econômica (superávit fiscal, cambio flutuante e meta de inflação) terminou por garantir taxas de juros reais elevadas e câmbio valorizado, o que seguiu alimentando os interesses da dominância financeira. Com isso, o deslocamento da manufatura para a Ásia seguiu, com o país reprimarizando a sua pauta de exportação que passou a responder por $36 \%$ dos produtos manufaturados, em 2014, contra 54,4\%, em 2003. 


\section{Considerações gerais}

O cenário de transformação interna exposto pela globalização ao Brasil revelou, em grande medida, o resultado das medidas de política econômica encaminhadas por diferentes governos desde a década de 1970. Naquela época, quando o conjunto dos investimentos representava quase $1 / 4$ do PIB, cerca de $1 / 3$ do total encontrava-se comprometido com máquinas e bens de equipamentos de renovação do parque produtivo nacional.

Decorrido 35 anos, a taxa de investimento responde por menos de $18 \%$ do Produto Interno Bruto, sendo menos de 1/6 do total envolvido com máquinas e bens de equipamentos de renovação do parque produtivo nacional. O sentido da estagnação da renda per capita confirma o esvaziamento da capacidade do capital industrial subordinar as forças produtivas, deixando por consequência de ser a liderança do motor de crescimento da economia brasileira.

Um conjunto de quatro tipos de respostas equivocadas terminou sendo orientado pela sucessão de governos que desde os anos de 1970 se mostraram incapazes de vencer a força da desindustrialização no país. O governo Geisel, na segunda metade da década de 1970 refugiou-se no programa de atualização retrógrada da indústria, buscando acertadamente substituir a importação em vários setores econômicos, porém equivocando-se substancialmente ao excluir os investimentos nos segmentos produtivos da terceira Revolução industrial e abusar simultânea e generalizadamente dos empréstimos externos.

No ano de 1980, a sequência equivocada da política econômica associada ao ajuste exportador decorrente de estatização da dívida externa terminou provocando o enquadramento defensivo do setor industrial. Resumidamente, a contração dos investimentos na modernização e o atraso 
tecnológico em meio à acomodação de altas margens de lucro favorecida pelo ambiente fechado à competição externa e altas taxas de inflação.

O equívoco maior parece ter se localizado na década de 1990, com a adoção das políticas econômicas neoliberais. A brusca abertura comercial, financeira e produtiva não apenas expôs irresponsavelmente o parque industrial sem oferecer condições isonômicas de competição externa, como levou à decomposição do Estado desenvolvimentista.

As consequências se expressaram no fechamento de empresas, fusões e internacionalização do parque produtivo, sobretudo com a privatização de parcela substancial do antigo setor produtivo estatal. A racionalização e especialização dos ramos industriais foram acompanhadas pelo enfraquecimento da burguesia industrial, cada vez mais subordinada à dominância financeira.

A centralidade da estabilização monetária desde o Plano Real tornou a inserção do Brasil na globalização mais dependente de sua face financeira do que comercial. Com isso, a substituição de parcela da produção nacional por produtos importados passou a revelar a transformação da antiga burguesia industrial em comerciante e rentista.

Por fim, os anos 2000 que apresentaram a continuidade do descenso do capital industrial, sobretudo após a crise de dimensão global iniciada em 2008. O equívoco na manutenção do tripé da política econômica herdada pelo Plano Real manteve fortemente o país prisioneiro das altas taxas de juros e da valorização cambial, o que se mostrou favorável à continuidade da subordinação do capital industrial à dominância financeira.

Não obstante os avanços socioeconômicos consideráveis, o período mais recente no Brasil não se mostrou suficiente para romper com a tendência à semiestagnação, sobretudo após o início da crise de dimensão global em 2008. Na base disso, encontra-se a grave continuidade do processo de desindustrialização nacional. 